\title{
Viewpoint on Emv2, the onlhy endogenous ecotropic murine leukemia virus of C57BL/6 mice
}

\author{
Christine A Kozak
}

\begin{abstract}
Here I comment on the articles by Lee and colleagues (Retrovirology 2011, 8:82) and Lee and Cho (Retrovirology

2012, 9:23) dealing with an endogenous ecotropic mouse leukemia virus found in C57BL mice.
\end{abstract}

\section{Viewpoint}

The paper by Lee and colleagues [1] and their additional comment on this work [2] argue that C57BL strain mice carry an endogenous ecotropic murine leukemia virus (E-MLV) with intact coding potential that may be distinct from the previously described Emv2. However, a review of the published literature and analysis of the sequenced genome do not support this view, as pointed out by Young and colleagues [3]. It is apparent that some confusion has resulted from the fact that the sequenced mouse genome is poorly annotated for retroviral sequences, from observations that the Emv2 provirus is replication incompetent, and because the original map location of Emv2 on the Chromosome (Chr) 8 linkage map is not precisely identical to its location on the database map Build. It is worthwhile elaborating on several points relevant to this issue: the fact that mice carrying only Emv2 can, in fact, produce infectious virus, and the evidence supporting the map location of this functional E-MLV provirus on distal Chromosome (Chr) 8 of C57BL mice.

Three different subtypes of E-MuLVs have been found in inbred and wild house mice, but only the AKV subtype is present in the common strains of laboratory mice. The different strains carry different numbers of these Emv proviruses inserted in different chromosomal locations [4,5]; this explains the detection of Emv2 sequences in many inbred strains by Lee et al. [1] using primers that are E-MuLV-, but not locus-specific, and also explains the presence of related sequences in $M . m$.

\footnotetext{
Correspondence: ckozak@niaid.nih.gov
Laboratory of Molecular Microbiology, National Institute of Allergy and

Correspondence: ckozak@niaid.nih.gov
Laboratory of Molecular Microbiology, National Institute of Allergy and Infectious Diseases, Bldg. 4, Room 329, 4 Center Drive MSC 0460, Bethesda, MD 20892-0460, USA
}

(c) 2012 Kozak; licensee BioMed Central Ltd. This is an Open Access article distributed under the terms of the Creative Commons Attribution License (http://creativecommons.org/licenses/by/2.0), which permits unrestricted use, distribution, and reproduction in any medium, provided the original work is properly cited.

molossinus, a wild mouse species previously shown to carry AKV-type Emv loci [6].

As pointed out by Young and colleagues [3], Southern blot analysis of C57BL DNA and examination of its sequenced genome identify one and only one ecotropic MLV provirus in this mouse strain that is found in the BAC RP23-214K5 (GenBank No. AC158362, position 97057-105700); this full-length provirus, Emv2, is 99.5\% identical to the infectious AKV MLV derived from Emv11 (J01998). A pol defect compromises the ability of the $E m v 2$ sequence to produce infectious virus when expressed in transfected cells [7]. However, Emv2 can and does produce E-MLV in vivo in aging C57BL mice [8] and cultured cells from these mice can also be induced by halogenated pyrimidines to produce ecotropic virus, although inefficiently compared to cells carrying other Emv proviruses [5,9]. This induction process is, however, efficient enough that $40 \%$ of individual mice from backcrosses between C57BL mice and E-MLV negative mice could be induced to produce infectious virus, which is consistent with inheritance of a single functional though poorly expressed provirus [5]. The fact that this provirus produces E-MLV in cultured cells relatively soon after induction suggests that the generation of infectious virus in mice carrying $E m v 2$ is a relatively common event, and likely results from recombination because expression is significantly enhanced in mice carrying Emv2 along with the fulllength but envelope-defective Emv1 [7,9,10]. The detection of virus expression by Lee et al. in C57BL mice [1] does not therefore warrant postulating the presence of a second locus.

The BAC carrying the C57BL E-MuLV maps to distal $\mathrm{Chr} 8$, and it should also be pointed out that the chromosomal map location of Emv2 was initially reported 
decades ago through analysis of C57BL backcross mice for the inherited ability to produce ecotropic virus after induction [5]. In multipoint genetic crosses, Emv2 (then termed $B v$ ) was positioned as being $23.5+/-4.2 \mathrm{cM}$ from the locus Got2 in two crosses, 25.9+/-4.8 cM from Ces1c (formerly Es1), and showed no linkage with the more proximal Chr 8 marker Gsr (formerly Gr1). The recombinational distances between the reference genes are consistent with their gene order and chromosomal positions in the sequenced genome, and with the map locations for these genes given by Mouse Genome Informatics (URL $=$ http://www.informatics.jax.org/). Other studies typed the CXB and BXH recombinant inbred (RI) lines for the Emv2 sequence and for its expression, and the cumulative marker typing information from these RI strains also positioned Emv2 on distal Chr 8 [9,11], as did analysis of Emv2 complementation of Emv1 in backcross mice [12]. This proviral locus was routinely included on maps of retroviral loci and on the developing linkage map of Chr 8 [13]. The Emv2 map locations defined by these various linkage analyses were determined with genetic methods that are crude by today's standards; these methods placed $E m v 2$ within a 95\% confidence interval of 8.4-10.7 cM on distal Chr 8, an interval defined by the frequency of recombinational events rather than by an actual physical distance. The data derived from these recombination-based studies are not, however, inconsistent with the position of this Emv in the sequenced genome.

\section{Conclusions}

It is clear from published work that the provirus identified in the Lee et al. study [1] is, in fact, Emv2, and no other tests are needed to accept this conclusion. Investigators should bear in mind that annotation of endogenous retroviral sequences in the sequenced mouse genome is incomplete, and that some of the available linkage maps represent best-guess consensus maps that attempt to incorporate data from disparate sources. Reliance on the information in databases does not therefore guarantee accurate characterization of individual ERVs, and it is therefore important to seek out primary sources for supporting documentation.

\section{Competing interests}

The author declares that they have no competing interests.

Received: 17 February 2012 Accepted: 22 March 2012 Published: 22 March 2012

\section{References}

1. Lee KH, Horiuchi M, Itoh T, Greenhalgh DG, Cho K: Cerebellum-specific and age-dependent expression of an endogenous retrovirus with intact coding potential. Retrovirology 2011, 8:82.

2. Lee K-H, Cho K: Reply to Emv2, the only endogenous ecotropic murine leukemia virus of C57BL/6J mice. Retrovirology 2012, 9:24.
3. Young GR, Kassiotis G, Stoye JP: Emv2, the only endogenous ecotropic murine leukemia virus of C57BL/6J mice. Retrovirology 2012, 9:23.

4. Jenkins NA, Copeland NG, Taylor BA, Lee BK: Organization, distribution, and stability of endogenous ecotropic murine leukemia virus DNA sequences in chromosomes of Mus musculus. J Virol 1982, 43:26-36.

5. Kozak CA, Rowe WP: Genetic mapping of ecotropic murine leukemia virus-inducing loci in six inbred strains. J Exp Med 1982, 155:524-534.

6. Kozak CA, O'Neill RR: Diverse wild mouse origins of xenotropic, mink cell focus-forming, and two types of ecotropic proviral genes. J Virol 1987, 61:3082-3088.

7. King SR, Berson BJ, Risser R: Mechanism of interaction between endogenous ecotropic murine leukemia viruses in (BALB/C X C57BL/6) hybrid cells. Virology 1988, 162:1-11.

8. Odaka T: Genetic transmission of endogenous $\mathrm{N}$ - and B-tropic murine leukemia viruses in low-leukemic strain C57BL/6. J Virol 1975, 15:332-337

9. McCubrey J, Risser R: Genetic interactions in induction of endogenous murine leukemia virus from low leukemic mice. Cell 1982, 28:881-888.

10. Horowitz JM, Risser R: Molecular and biological characterization of the endogenous ecotropic provirus of BALB/C mice. J Virol 1985, 56:798-806.

11. Jenkins NA, Copeland NG, Taylor BA, Bedigian HG, Lee BK: Ecotropic murine leukemia virus DNA content of normal and lymphomatous tissues of BXH-2 recombinant inbred mice. J Virol 1982, 42:379-388.

12. McCubrey J, Risser R: Allelism and linkage studies of murine leukemia virus activation genes in low leukemic strains of mice. J Exp Med 1982, 155:1233-1238.

13. Ceci JD, Mills KA: Encyclopedia of the mouse genome VII. Mouse chromosome 8. Mamm Genome 1998, 8 Spec No:S160-S179.

doi:10.1186/1742-4690-9-25

Cite this article as: Kozak: Viewpoint on Emv2, the onlhy endogenous ecotropic murine leukemia virus of C57BL/6 mice. Retrovirology 2012 $9: 25$

\section{Submit your next manuscript to BioMed Central and take full advantage of:}

- Convenient online submission

- Thorough peer review

- No space constraints or color figure charges

- Immediate publication on acceptance

- Inclusion in PubMed, CAS, Scopus and Google Scholar

- Research which is freely available for redistribution

Submit your manuscript at www.biomedcentral.com/submit 